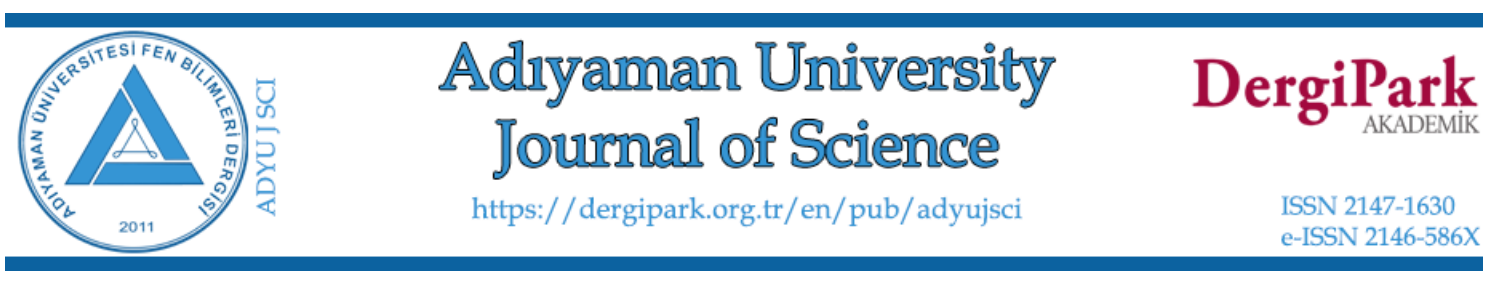

\title{
Exchange Bias Effect in NiMnSbB Ferromagnetic Shape Memory Alloys \\ Depending on Mn Content
}

\author{
Gökhan KIRAT ${ }^{1, *}$ \\ ${ }^{1}$ Inonu University, Scientific and Technological Research Center, 44280 Malatya, Türkiye, \\ gokhan.kirat@inonu.edu.tr,ORCID:0000-0001-7357-2921
}

\begin{tabular}{lll}
\hline Received: 25.08 .2021 & Accepted: 03.12.2021 & Published: 31.12.2021
\end{tabular}

\begin{abstract}
In this study, exchange bias effect was investigated in boron added NiMnSb Heusler alloys. The samples were fabricated by arc melting method with $\mathrm{Ni}_{49} \mathrm{Mn}_{37.5} \mathrm{Sb}_{13.5}+\mathrm{B}_{\mathrm{x}}, \mathrm{Ni}_{49} \mathrm{Mn}_{37.7} \mathrm{Sb}_{13.3}+\mathrm{B}_{\mathrm{x}}$ and $\mathrm{Ni}_{49} \mathrm{Mn}_{37.9} \mathrm{Sb}_{13.1}+\mathrm{B}_{\mathrm{x}}$ nominal compositions. XRD analyzes showed that the samples were in L2 ${ }_{1}$ crystal structure at room temperature. While the martensitic phase transition temperatures increased, the magnetic moment value decreased with the increase in Mn content. The decrease in magnetization is resulted from increase in antiferromagnetic interactions with the increase of Mn content. Under low field and zero field cooling M-T measurements revealed that antiferromagnetic interactions were more dominant at low temperature but ferromagnetic behavior was more effective in the system at high temperature region. The coexistence of ferromagnetism and antiferromagnetism in a magnetic material can cause the exchange bias effect. Therefore, the hysteresis loops were examined at $5 \mathrm{~K}$ of the samples cooled under $50 \mathrm{kOe}$ magnetic field. The shift at the origin of the magnetization curve, which is attributed to the exchange bias effect, increased with increasing Mn amount.
\end{abstract}

Keywords: Ferromagnetic shape memory effect; NiMnSb Heusler alloys; Exchange bias effect, Antiferromagnetic interactions. 


\section{Bor Eklenmiş NiMnSb Ferromanyetik Şekil Hatırlamalı Alaşımlarda Exchange Bias Etkisi}

\section{$\ddot{O} z$}

$\mathrm{Bu}$ çalışmada bor eklenmiş NiMnSb Heusler alaşımlarında exchange bias etkisi araştırılmıştır. Numuneler, $\mathrm{Ni}_{49} \mathrm{Mn}_{37.5} \mathrm{Sb}_{13.5}+\mathrm{B}_{\mathrm{x}}, \mathrm{Ni}_{49} \mathrm{Mn}_{37.7} \mathrm{Sb}_{13.3}+\mathrm{B}_{\mathrm{x}}$ ve $\mathrm{Ni}_{49} \mathrm{Mn}_{37.9} \mathrm{Sb}_{13.1}+\mathrm{B}_{\mathrm{x}}$ başlangıç kompozisyonunda ark ergitme yöntemiyle üretildi. XRD analizleri, örneklerin oda sıcaklığında L2 ${ }_{1}$ kristal yapısında olduğunu gösterdi. Mn içeriğinin artmasıyla martensitik faz geçiş sıcaklıkları artarken manyetik moment değeri azalmaktadır. Manyetizasyondaki azalma, Mn içeriğinin artmasıyla antiferromanyetik etkileşimlerdeki artıştan kaynaklanmaktadır. Düşük alan ve sıfır alan soğutması altındaki M-T ölçümleri, düşük sıcaklıkta antiferromanyetik etkileşimlerin daha baskın olduğunu, ancak yüksek sıcaklık bölgesinde sistemde ferromanyetik davranışın daha etkili olduğunu ortaya koydu. Manyetik bir malzemede ferromanyetizma ve antiferromanyetizmanın bir arada bulunmas1, exchange bias etkisine neden olabilir. Bu nedenle, 50 kOe manyetik alan altında soğutulan numunelerin $5 \mathrm{~K}$ 'de histerezis döngüleri incelenmiştir. Exchange bias etkisine atfedilen manyetizasyon eğrisinin orijinindeki kayma, artan Mn miktarı ile artmıştır.

Anahtar Kelimeler: Ferromanyetik şekil hatırlama etkisi; NiMnSb Heusler alaşımları; Exchange bias etkisi; Antiferromanyetik etkileşimler.

\section{Introduction}

Shape memory alloys (SMAs) are extensively studied by scientists and industrial organizations due to their useful mechanical properties. As a result of these studies, nowadays SMAs are used in many technological applications such as orthodontic braces and cardiovascular stents used to open occluded or narrowed vessels, as well as industrial applications such as sensitive thermal sensors, medical devices, electronic devices, spacecraft, superelastic eyeglass frames and building materials [1]. While the shape memory effect can be activated by heat in classical SMAs, in ferromagnetic shaped alloys (FSMAs), in addition to heat, it can be achieved with an external magnetic field. The fact that the shape memory mechanism is faster than classical SMAs increases the interest in FSMAs. FSMAs, which can be activated sensitively by magnetic field, have various usage areas such as sensors, magnetic coolers and actuators [2].

The exchange bias (EB) term is used to describe the shift of the hysteresis loop along the magnetic field axis. The origin of this phenomenon is the exchange interaction between antiferromagnetic (AFM) and ferromagnetic (FM) spin structures. EB occurs when a FM and an 
AFM spin structures are in contact, and the system is cooled from high temperatures through the Néel temperature of the AFM in an external magnetic field [3].

FSMAs are very convenient to be used in practical applications as it exhibits the shape memory effect and strong magnetization simultaneously. Ferromagnetic $\mathrm{Ni}_{2} \mathrm{MnZ}$ ( $Z=\mathrm{In}, \mathrm{Sn}, \mathrm{Sb}$ ) Heusler alloys (HAs) have been studied extensively in recent years due to their multifunctional physical properties and magnetic behavior in martensitic transformation. Ni-Mn based HAs have attracted considerable attention in the family of shape memory alloys since they exhibit useful physical properties such as magnetic shape memory effect, magnetocaloric effect, magnetoresistance, elastacaloric effect [4].

During the martensitic transformation, the high temperature phase called austenite transforms into a low temperature phase called martensite. It has been reported that the crystal structure transforms from L2 1 (high temperature) to $10 \mathrm{M}, 14 \mathrm{M}$ or $\mathrm{L} 1_{0}$ (low temperature) with starting martensitic transformation [5, 6]. Since the martensite phase has less symmetry, its magnetic state is not very clear [7]. Generally, the magnetization of HAs is caused by Mn atoms. The nearest neighbor distance between $\mathrm{Mn}$ atoms in $\mathrm{Ni}_{2} \mathrm{MnGa}$ alloys is about $0.4119 \mathrm{~nm}$. The Ruderman-Kittel-Kaeya-Yo exchange interaction mediated by the conduction electrons gives rise to a ferromagnetic ordering. In Mn-rich HAs, extra Mn atoms occupy $\mathrm{Z}$ sites, therefore the distance between $\mathrm{Mn}$ atoms suddenly decreases (for $\mathrm{Ni}_{2} \mathrm{Mn}_{1+\mathrm{x}} \mathrm{Ga}_{1-\mathrm{x}} \mathrm{x}>0$ about $0.2912 \mathrm{~nm}$ ) and at such small distances, the magnetic moments preferably align as antiparallel in both high and low temperatures phases of the alloy [8]. With the increase of AFM interactions, which can be expected that the EB property will improve.

In this study, boron-doped NiMnSb SMAs were produced in ingot form by arc melting method. The martensite transition temperatures, hysteresis properties and magnetic properties of the produced samples were revealed by magnetization measurements depending on temperature and magnetic field. As explained above, AFM interactions are expected to increase by decreasing the distance between $\mathrm{Mn}$ atoms due to the rich Mn content. It is aimed to improve the EB property by increasing AFM interactions. Therefore, the EB properties of the samples will be investigated in the last stage of the study.

\section{Experimental}

Polycrystalline $\mathrm{Ni}_{49} \mathrm{Mn}_{37.5} \mathrm{Sb}_{13.5}+\mathrm{B}_{\mathrm{x}}, \mathrm{Ni}_{49} \mathrm{Mn}_{37.7} \mathrm{Sb}_{13.3}+\mathrm{B}_{\mathrm{x}}$ and $\mathrm{Ni}_{49} \mathrm{Mn}_{37.9} \mathrm{Sb}_{13.1}+\mathrm{B}_{\mathrm{x}}$ ingots were produced by arc melting method in argon atmosphere. Samples were remelted several times to ensure homogenization. Mn evaporation at the production process makes it difficult to fabricate HAs at the desired stoichiometry $[9,10]$. We reported that Mn evaporation was significantly 
inhibited in boron added Ni-Mn-Sn HAs [2, 4]. It can be expected that Boron addition exhibited similar results in Ni-Mn-Sb alloys. Therefore, 3 moles boron were added to each sample and it is also known that excess B in the ingots can leads to fragility of the alloys. The ingot samples were heat treated in vacuumed quartz ampoules at $1173 \mathrm{~K}$ for $48 \mathrm{~h}$, and then quenched in ice-water. The samples were marked as Sb-13.5, Sb-13.3 and Sb-13.1, respectively.

X-ray diffraction (XRD) for the structural characterization was performed with $\mathrm{CuK} \alpha$ radiation in the Rigaku Miniflex 600 device.

Martensitic phase transition temperatures were found by temperature dependent magnetization (M-T) measurements. M-T measurements were performed under constant $100 \mathrm{Oe}$ and $10 \mathrm{kOe}$ magnetic fields between $5 \mathrm{~K}$ and $350 \mathrm{~K}$, both heating and cooling. Magnetization dependent on magnetic field $(\mathrm{M}-\mathrm{H})$ measurements of ingots were measured at $5 \mathrm{~K}$ and $325 \mathrm{~K}$ up to the magnetic field of $\pm 9 \mathrm{~T}$. To determine the EB properties, the samples were cooled to $5 \mathrm{~K}$ under $50 \mathrm{kOe}$ magnetic field. The shifts in the origin of the magnetization curve were investigated by the M-H measurements of the samples cooled under the field. All magnetic moment measurements were carried out with VSM attachment of Quantum Design PPMS-9T system.

\section{Results and Discussions}

The XRD patterns of the Sb-13.5, Sb-13.3 and Sb-13.1 samples are shown in Fig. 1. It was determined that the samples were in the bcc $\mathrm{L} 2{ }_{1}$ crystal structure, so the samples used in the study are expected to be in the austenite phase at room temperature. The lattice parameter, for $\mathrm{Sb}-13.5$, Sb-13.3 and Sb-13.1 samples were calculated to be $0.5955 \mathrm{~nm}, 0.5952 \mathrm{~nm}$ and $0.5948 \mathrm{~nm}$, respectively, using Rietveld refnement. The lattice parameter decreased by decreasing the amount of $\mathrm{Sb}$ and increasing the $\mathrm{Mn}$ atoms with smaller radius simultaneously. Consequently, unit cell of austenite phase shrinks with increasing Mn content. The obtained results reveal that the interatomic distance between Mn-Mn decreases by replacing Sb with Mn. Although the intensity of the main peak (220) was obtained in the highest Sb-13.5 sample, no significant difference was observed in the XRD patterns of the samples. In addition, any peak attributable to impurity was not found. Ni-Mn based alloys that exhibit the shape memory effect generally have a cubic L $2_{1}$ crystal structure in the austenite phase. Therefore, the samples can be expected to be in the austenite phase at room temperature. 


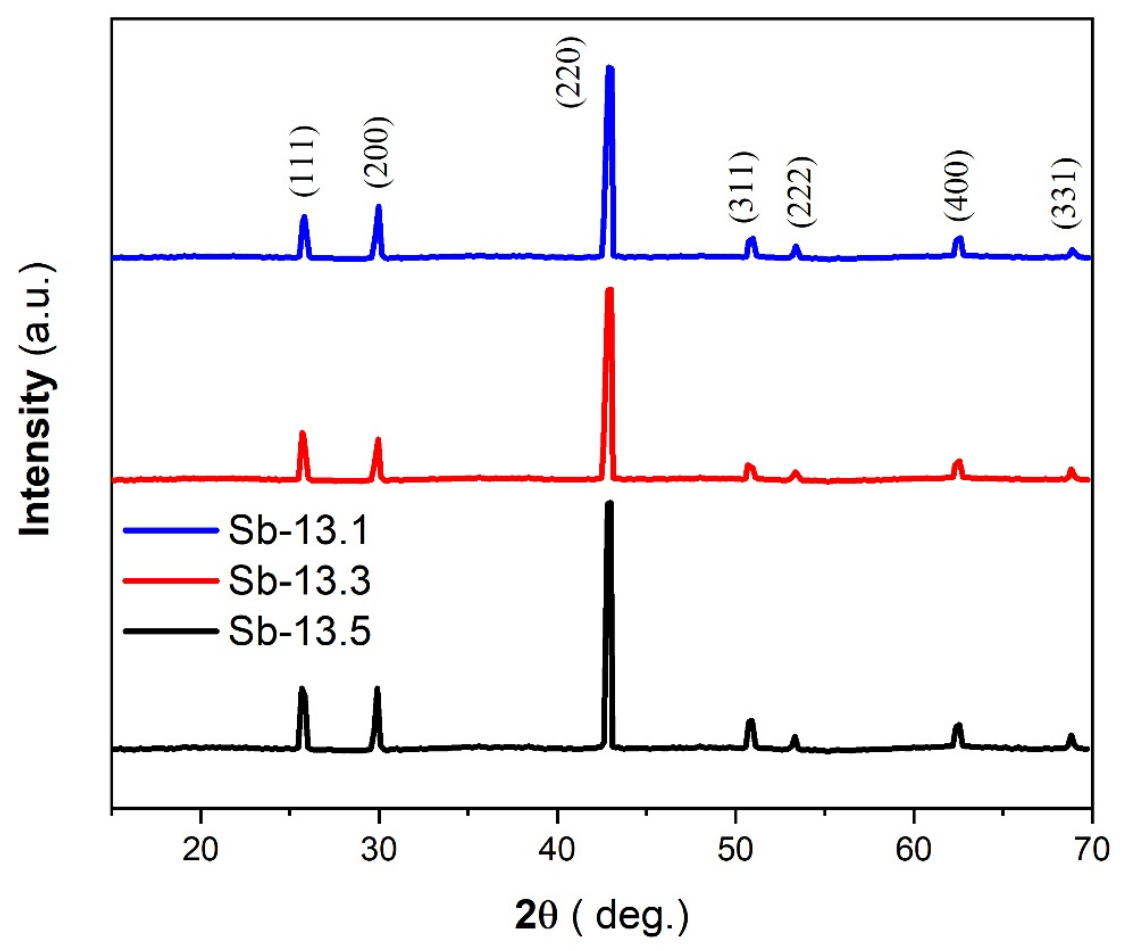

Figure 1: XRD pattern of Sb-13.5, Sb-13.3 and Sb-13.1

During the martensitic transformation, the austenite phase with high crystallographic symmetry (usually cubic) transforms into a martensite phase (like tetragonal and orthorhombic) with a lower order parameter [11]. When austenite to martensite phase transformation occurs in FSMAs, a sharp decrease in magnetization occurs due to the decrease in the order parameter in the crystal structure and vice versa. Additionally, a thermal hysteresis occurs during the phase transition because of the twin boundaries formed in the martensite phase and friction at the twin boundaries [12]. Temperature dependent magnetization curves (M-T) of the Sb-13.5, Sb-13.3 and Sb-13.1 samples are given in Fig. 2. According to the obtained results, all samples exhibited martensitic transformation. It was determined that all samples exhibited martensitic transformation and the phase transition temperature increased with increasing Mn content. The changing of the martensitic transition temperatures is usually attributed to the number of valence electrons per atom (e/a) and the unit-cell volume of the austenite phase. The phase transition temperature is usually directly proportional to e/a. If the e/a effect is analyzed in terms of the band model: Austenite with L2 $2_{1}$ crystal structure is stabilized since the Fermi surface just touches the (110) Brillouin zone. By increasing e/a, the Fermi surface and (110) Brillouin regions overlap; and as a result, excessive increase in system energy leads to lattice distortion to minimize free energy, i.e. martensite formation. The second factor affecting the phase transition temperatures is the atomic size effect. It is widely accepted that unit cell shrinkage of austenite at high temperature will promote martensitic transformation due to changes in the relative positions between the Fermi 
surface and the Brillouin zone. As a result, increasing the Mn content raises the e/a ratio, thus causing an increase in the phase transition temperature [13].

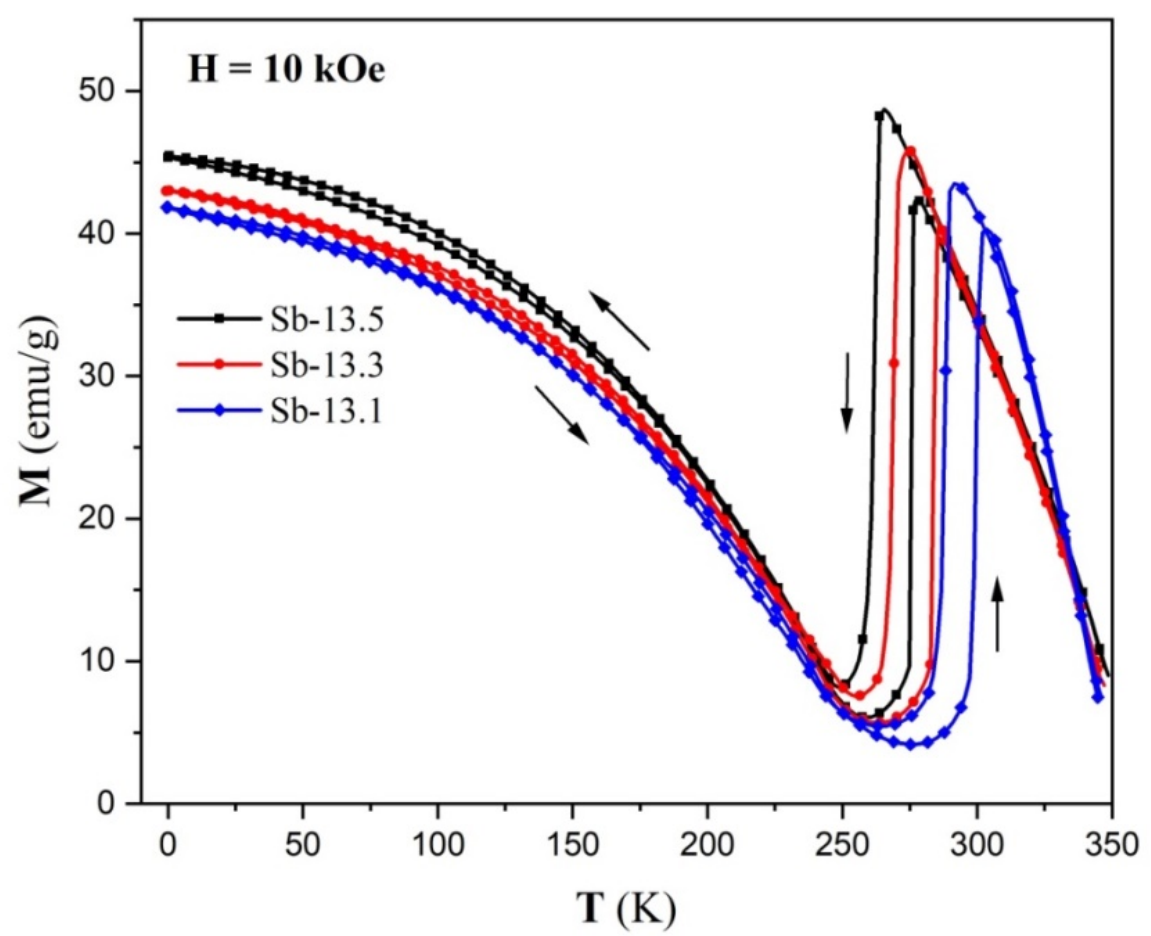

Figure 2: M-T curves of the Sb-13.5, Sb-13.3 and Sb-13.1 samples at $10 \mathrm{kOe}$

Another notable point in Fig. 2 is reducing in magnetic moment depend on Mn content. The maximum magnetic moment value decreased with the increase of Mn content. The contribution of $\mathrm{Ni}$ to the total magnetization is quite low since $\mathrm{Ni}$ atoms in Ni-Mn-X ( $\mathrm{X}=\mathrm{Sn}, \mathrm{Sb}$, In) alloys have an antiparallel spin arrangement. The total magnetic moment is mostly calculated from the spin moments of $\mathrm{Mn}$ atoms $[14,15]$. Since the exchange interactions in HAs depend on the distance between $\mathrm{Mn}$ and $\mathrm{Mn}$, the magnetization and phase transformation temperatures are highly dependent on the chemical composition [16]. The magnetic properties of HAs can be modified by changing the distance between Mn atoms. If the Mn content of HAs $\left(\mathrm{Ni}_{50} \mathrm{Mn}_{25+\times} \mathrm{Sb}_{25}\right.$ x) is greater than 25, extra $\mathrm{Mn}$ atoms will occupy the $\mathrm{Sb}$ site. The distance between $\mathrm{Mn}$ atoms gets shorter and its spin moment will be antiparallel to that of other Mn atoms at Mn sites. An increase in antiparallel interactions causes a decrease in the maximum magnetic moment value in the FSMAs [15]. 


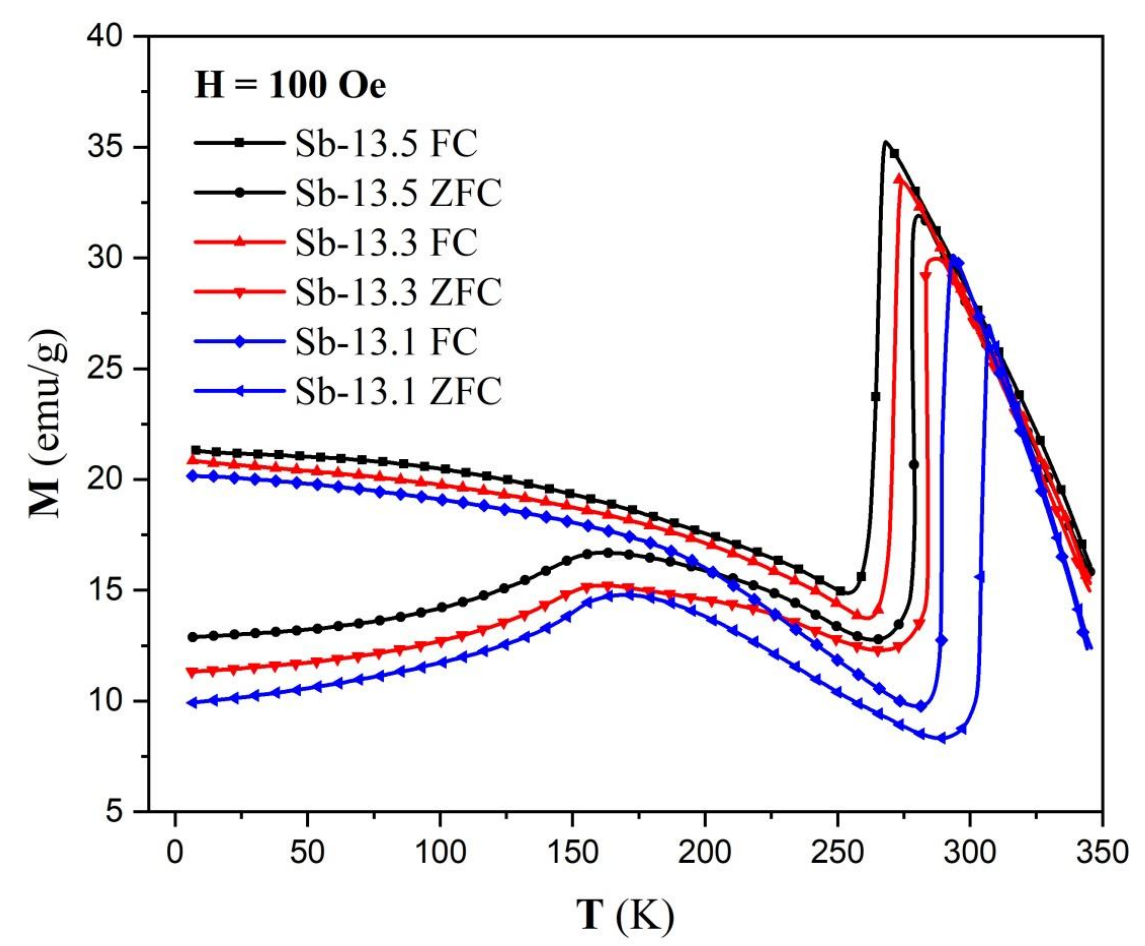

Figure 3: ZFC and FC M-T curves of the Sb-13.5, Sb-13.3 and Sb-13.1 samples at $100 \mathrm{Oe}$

Although it is expected that antiferromagnetic interactions will increase with increasing $\mathrm{Mn}$ amount, there is no data that can be direct evidence of the existence in antiferromagnetic interactions in Fig. 2 because the spin alignment of the materials is strongly affected by the 10 kOe magnetic field. Therefore, temperature-dependent magnetization measurements were carried out in both ZFC (Zero Field Cooling) and FC (Field Cooling) regimes at a relatively low magnetic field. Firstly, the samples were cooled to $5 \mathrm{~K}$ without a field, then the measurements were carried out by applying the field (100 Oe). In the final step, the magnetizations of the cooled samples were measured under 100 Oe field. The obtained results are shown in Fig. 3. It is clear that magnetization increases with increasing temperature in the low temperature region (between $5 \mathrm{~K}$ and $\sim 175 \mathrm{~K}$ ) in all samples. This increase is a common characteristic behavior of AFM. When the temperature rises above about $175 \mathrm{~K}$, magnetization decreases. It shows that ferromagnetic interaction is more dominant in this region. With the further increase in temperature, phase transitions occurred at different temperatures for each sample and a sharp increase in magnetization occurred. In cooling M-T (FC) analyses, magnetization increases continuously after the completion of the martensitic phase transition due to permanent magnetization. When M-T curves in high magnetic field (10 kOe Fig. 2) and low magnetic field (100 Oe Fig. 3) are compared, phase transition temperatures decrease with increasing field. Martensitic phase transition temperatures are listed in Table 1. 
Table 1: Martensitic phase transition temperatures of the samples

\begin{tabular}{cccccc}
\hline Sample & Magnetic Field & $\mathbf{A}_{\mathbf{s}}(\mathbf{K})$ & $\mathbf{A}_{\mathbf{f}}(\mathbf{K})$ & \multirow{2}{*}{$\mathbf{M}_{\mathbf{s}}(\mathbf{K})$} & $\mathbf{M}_{\mathbf{f}}(\mathbf{K})$ \\
\hline Sb-13.5 & $100 \mathrm{Oe}$ & 270.41 & 279.56 & 268.17 & 255.77 \\
& $10 \mathrm{kOe}$ & 267.16 & 277.14 & 264.83 & 249.40 \\
Sb-13.3 & $100 \mathrm{Oe}$ & 278.42 & 287.14 & 274.22 & 264.23 \\
& $10 \mathrm{kOe}$ & 274.97 & 286.03 & 273.55 & 257.96 \\
Sb-13.1 & $100 \mathrm{Oe}$ & 297.39 & 307.23 & 292.32 & 284.90 \\
& $10 \mathrm{kOe}$ & 292.97 & 302.38 & 290.51 & 279.38 \\
\hline
\end{tabular}
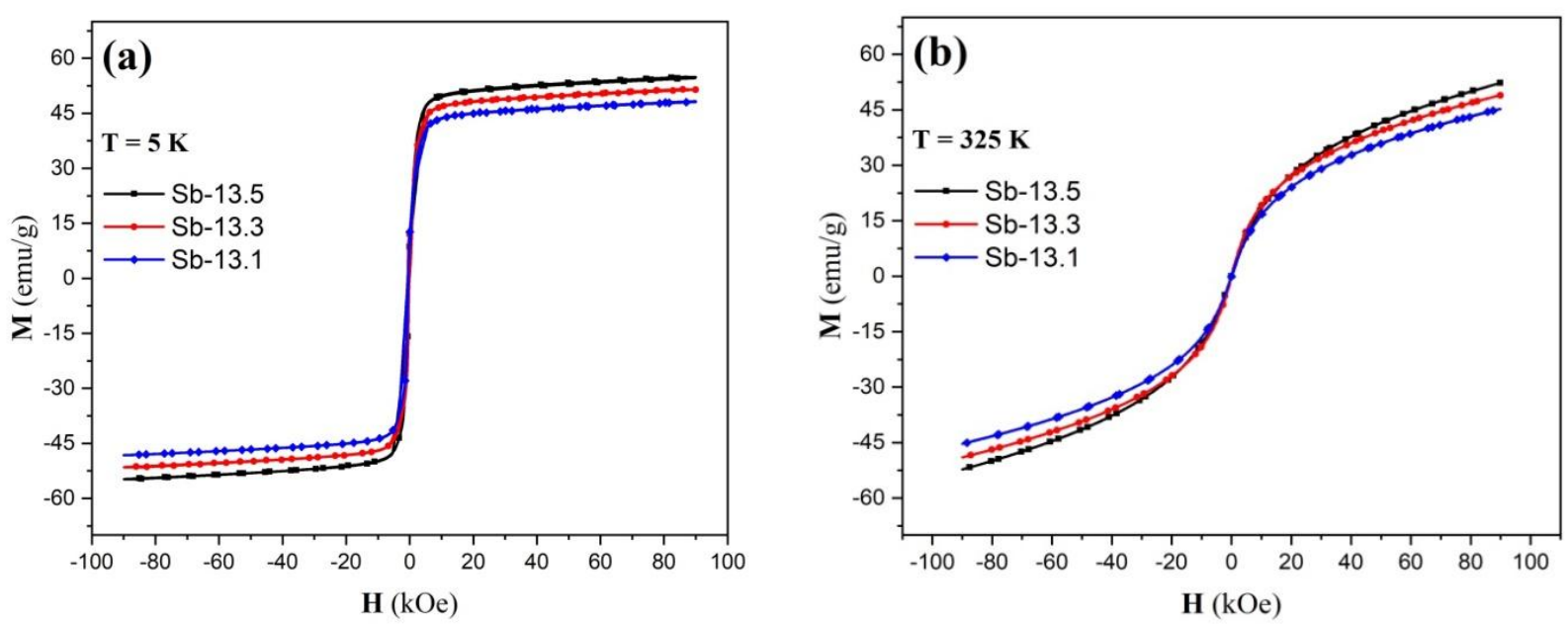

Figure 4: $\mathrm{M}-\mathrm{H}$ results of the samples (a) at $5 \mathrm{~K}$ (b) at $325 \mathrm{~K}$

Magnetization vs applied magnetic field (M-H) curves of the samples at $5 \mathrm{~K}$ and $325 \mathrm{~K}$ are presented in Fig. $4 \mathrm{a}$ and $4 \mathrm{~b}$, respectively. While the magnetization saturates quickly at $5 \mathrm{~K}$, they did not reach saturation at $325 \mathrm{~K}$. Consistent with the M-T analysis, the highest magnetization value was obtained in the Sb-13.5 sample. As the Mn content increases, a contraction occurs in the unit cell and distance between $\mathrm{Mn}$ atoms becomes shorter. Mn atoms nearing each other more than the critical distance prefer antiparallel spin alignment. Therefore, a decrease occurs in total magnetization. 

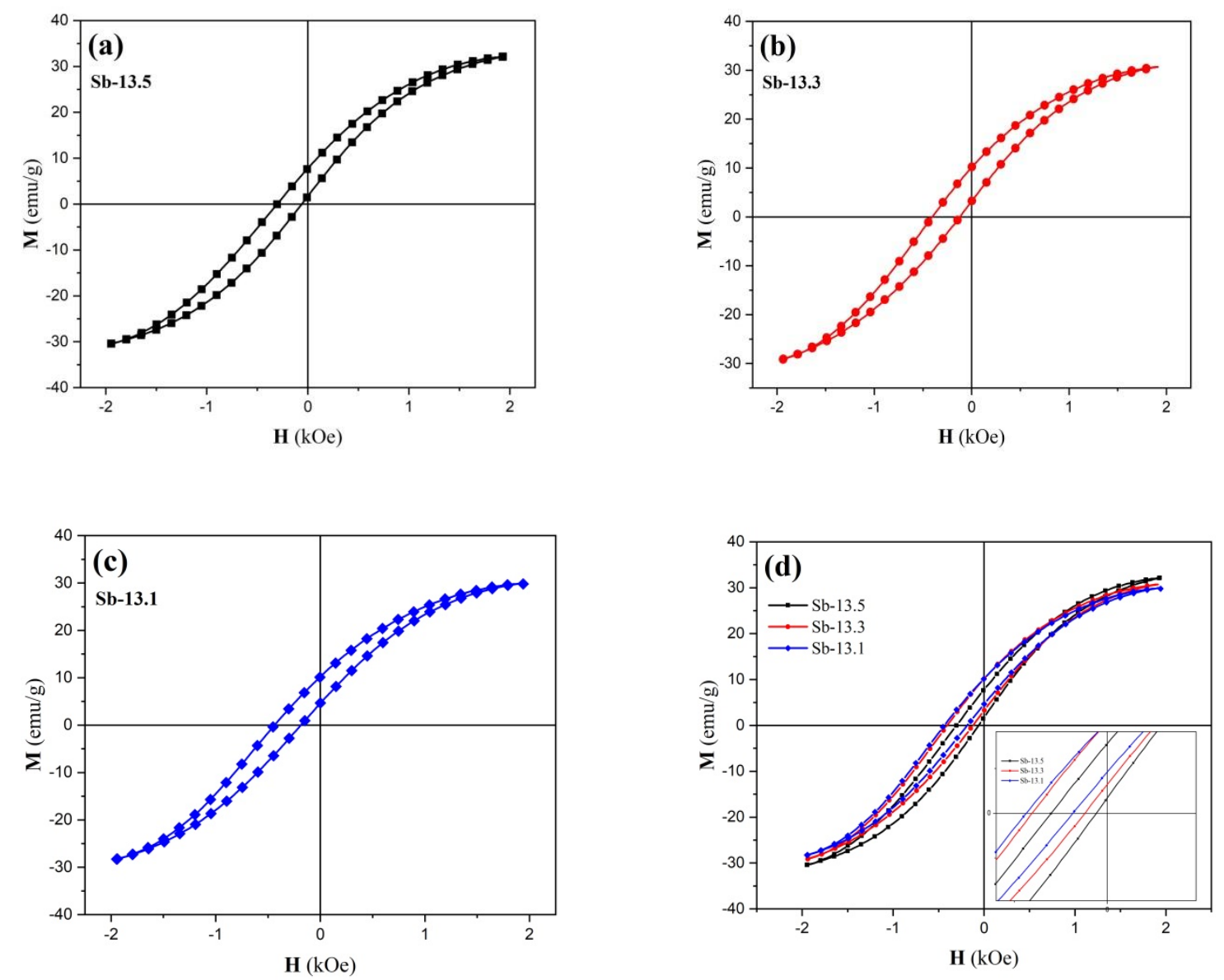

Figure 5: Hysteresis loops of the (a) Sb-13.5 (b) Sb-13.3 (c) Sb-13.1 and (d) overlapped for all samples at $5 \mathrm{~K}$

The origin of the EB effect is fundamentally the exchange interaction that occurs at the interface of the antiferromagnetic and ferromagnetic phases. In the absence of an external magnetic field, the AFM has no net magnetization or is very small. With the application of the external magnetic field, the spins of the soft FM phase rapidly rotate in the same direction as the field. The spins of the AFM phase close to the AFM-FM interface are affected by this strong magnetization and they become the same alignment with FM phase. If the added energy is enough to create a Néel domain wall within the AFM, it implies a shift in the switching field of the FM. As a result, a shift occurs in the origin of the magnetization curve [17]. For the EB effect to occur, $\mathrm{T}_{\mathrm{N}}$ (Néel temperature) should be lower than $\mathrm{T}_{\mathrm{C}}$ (Curie temperature) [7]. To examine the EB effect, the samples were cooled under $50 \mathrm{kOe}$ magnetic field and $\mathrm{M}-\mathrm{H}$ measurements were carried out at $5 \mathrm{~K}$. The obtained hysteresis loops are given separately for each sample (Fig. 5a-c) and overlapped for all samples (Fig. 5d). The shift to the centers of origins attributed to the EB effect is clearly visible from Fig. 5. The obtained data from the XRD revealed that the unit cell narrowed by decreasing the $\mathrm{Sb}$ content and increasing the Mn. As discussed above, with decreasing the distance between atoms, the AFM interactions increase between Mn atoms. With increasing AFM 
interactions, the EB effect and hence the shift in the origin of the hysteresis increases. EB is mainly connected to the coexistence of FM-AFM interfaces [18]. Therefore, the presence of EB in HAs is a proof that AFM interactions are present in the system. This indicates that there is an AFM interaction inside the FM matrix at low temperatures. Currently, the effect of EB in FSMAs is not completely understood as $T_{N}$ is not clearly determined in these materials [19]. Besides, the EB field $\left(\mathrm{H}_{\mathrm{EB}}\right)$ can be determined from Fig. 5 as a function of Mn content. The $\mathrm{H}_{\mathrm{EB}}$ is defined as $\mathrm{H}_{\mathrm{EB}}=-\left(H_{1}+H_{2}\right) / 2$. Here, $H_{1}$ and $H_{2}$ are the left and right coercive fields, respectively [20-23]. $\mathrm{H}_{\mathrm{EB}}$ values of Sb-13.5, Sb-13.3 and Sb-13.1 samples were calculated as $340 \mathrm{Oe}, 600 \mathrm{Oe}$ and $820 \mathrm{Oe}$, respectively.

\section{Conclusion}

In this study, the $\mathrm{Ni}_{49} \mathrm{Mn}_{37.5} \mathrm{Sb}_{13.5}+\mathrm{B}_{\mathrm{x}}, \mathrm{Ni}_{49} \mathrm{Mn}_{37.7} \mathrm{Sb}_{13.3}+\mathrm{B}_{\mathrm{x}}$ and $\mathrm{Ni}_{49} \mathrm{Mn}_{37.9} \mathrm{Sb}_{13.1}+\mathrm{B}_{\mathrm{x}}$ ingots were fabricated by arc melting method. It was determined that the produced samples were in cubic $\mathrm{L} 2{ }_{1}$ structure at room temperature with XRD analysis. Mn evaporation complicates the production of HAs. Boron was added to the nominal compositions to prevent Mn evaporation (3 mol). M-T analyzes at $10 \mathrm{kOe}$ showed that all samples exhibited martensitic transformation. The phase transition temperature increased with increasing the content of Mn in accordance with the e/a rule. In HAs with excess $\mathrm{Mn}$, the distance between $\mathrm{Mn}$ atoms becomes shorter and $\mathrm{Mn}$ atoms prefer an AFM alignment. ZFC and FC M-T measurements were performed at low magnetic field (100 Oe) to determine the antiferromagnetic behavior of the samples. ZFC measurements revealed that antiferromagnetism was dominant in the $5-175 \mathrm{~K}$ range. In the high temperature region, ferromagnetism exhibited a more dominant behavior. Magnetic field dependent magnetization measurements showed that $\mathrm{Mn}$ content and magnetization were inversely proportional. This is due to the increase of antiferromagnetic interactions in the ferromagnetic matrix with increasing Mn content. The EB effect, which is important for technological applications, was investigated in the last part. It was concluded that the EB effect was improved with the increase of Mn content. Besides, these results are evidence for the existence of antiferromagnetic interactions in HAs, especially at low temperatures.

\section{References}

[1] Asai, M., Suzuki, Y., Applications of shape memory alloys in Japan, Materials Science Forum, 327-328, 17-22, 2000.

[2] Kirat, G., Kizilaslan, O., Aksan, M.A., Magnetoresistance properties of magnetic Ni$M n-S n-B$ shape memory ribbons and magnetic field sensor aspects operating at room temperature, Journal of Magnetism and Magnetic Materials, 477, 366-371, 2019.

[3] Blachowicz, T., Ehrmann, A., Exchange bias in thin films-an update, Coatings, 11, 1- 
$21,2021$.

[4] Kirat, G., Aksan, M.A., Aydogdu, Y., Magnetic field induced martensitic transition in Fe doped Ni-Mn-Sn-B shape memory ribbons, Intermetallics, 111, 106493, 2019.

[5] Sánchez Llamazares, J.L., Sanchez, T., Santos, J.D., Ṕrez, M.J., Sanchez, M.L., Hernando, B., Escoda, L., Suñol, J.J., Varga, R., Martensitic phase transformation in rapidly solidified $\mathrm{Mn}_{50} \mathrm{Ni}_{40} \mathrm{In}_{10}$ alloy ribbons, Applied Physics Letters, 92, 8-11, 2008.

[6] Bachagha, T., Zhang, J., Sunol, J.J., Khitouni, M., Martensitic transformation and magnetic behavior in Mn-rich Heusler MnNiIn shape memory alloys, IOP Conference Series Materials Science and Engineering, 504, 012009, 2019.

[7] Wang, B.M., Liu, Y., Wang, L., Huang, S.L., Zhao, Y., Yang, Y., Zhang, H., Exchange bias and its training effect in the martensitic state of bulk polycrystalline $\mathrm{Ni}_{49.5} \mathrm{Mn}_{34.5} \operatorname{In}_{16}$, Journal of Applied Physics, 104, 043916, 2008.

[8] Yu, S.Y., Cao, Z.X., Ma, L., Liu, G.D., Chen, J.L., Wu, G.H., Realization of magnetic field-induced reversible martensitic transformation in NiCoMnGa alloys, Applied Physics Letters, 91, 102507, 2007.

[9] Maziarz, W., Czaja, P., Wójcik, A., Dutkiewicz, J., Przewoźnik, J., Cesari, E., Microstructure and martensitic transformation of $\mathrm{Ni}_{50} \mathrm{Mn}_{37.5} \mathrm{Sn}_{12.5-x} \mathrm{Ge} e_{x}(\mathrm{X}=0,1,2,3)$ Heusler alloys produced by various Technologies, Materials Today: Proceedings, 2(3), S523-S528, 2015.

[10] Yu, J.K., Li, H.W., Zhai, Q.J., Fu, J.X., Luo, Z.P., Zheng, H.X., Crystal structure and formation mechanism of the secondary phase in Heusler Ni-Mn-Sn-Co materials. Advances in Manufacturing, 2, 353-357, 2014.

[11] Zelený, M., Straka, L., Sozinov, A., Heczko, O., Transformation paths from cubic to low-symmetry structures in Heusler Ni $i_{2} \mathrm{MnGa}$ compound, Scientific Reports, 8, 7275, 2018.

[12] Wang, W.-H., Chen, J.-L., Liu, Z., Wu, G.-H., Zhan, W.-S., Thermal hysteresis and friction of phase boundary motion in ferromagnetic $\mathrm{Ni}_{52} \mathrm{Mn}_{23} \mathrm{Ga}_{25}$ single crystals, Physical Review B, 65, 012416, 2001.

[13] Zheng, H., Wang, W., Xue, S., Zhai, Q., Frenzel, J., Luo, Z., Composition-dependent crystal structure and martensitic transformation in Heusler Ni-Mn-Sn alloys, Acta Materialia, 61, 4648-4656, 2013.

[14] Kübler, J., William, A.R., Sommers, C.B., Formation and coupling of magnetic moments in Heusler alloys, Physical Review B, 28, 1745-1755, 1983.

[15] Luo, H., Meng, F., Jiang, Q., Liu, H., Liu, E., Wu, G., Wang, Y., Effect of boron on the martensitic transformation and magnetic properties of $\mathrm{Ni}_{50} \mathrm{Mn}_{36.5} \mathrm{Sb}_{13.5-x} \mathrm{~B}_{x}$ alloys, Scripta Materialia, 63(6), 569-572, 2010.

[16] Hernando, B., Llamazares, J.L.S., Santos, J.D., Sánchez, M.L., Escoda, L., Suñol, J.J., Varga, R., García, C., González, J., Grain oriented NiMnSn and NiMnIn Heusler alloys ribbons produced by melt spinning: Martensitic transformation and magnetic properties, Journal of Magnetism and Magnetic Materials, 321(7), 763-768, 2009.

[17] Stamps, R.L., Mechanisms for exchange bias, Journal of Physics D: Applied Physics, 33(23), R247-R268, 2000.

[18] Czaja, P., Przewoźnik, J., Fitta, M., Bałanda, M., Chrobak, A., Kania, B., Zackiewicz, 
P., Wójcik, A., Szlezynger, M., Maziarz, W., Effect of ball milling and thermal treatment on exchange bias and magnetocaloric properties of $\mathrm{Ni}_{48} \mathrm{Mn}_{39.5} \mathrm{Sn}_{10.5} \mathrm{Al}_{2}$ ribbons, Journal of Magnetism and Magnetic Materials, 401, 223-230, 2016.

[19] Acet, M., Mañosa, L., Planes, A., Magnetic-Field-Induced effects in martensitic Heusler-based magnetic shape memory alloys, Handbook of Magnetic Materials, 19, 231-289, 2011.

[20] Li, S., Wang, S., Lu, Y., Zhang, C., Yang, X., Gao, J., Li, D., Zhu, Y., Liu, W., Exchange bias effect in hybrid improper ferroelectricity $\mathrm{Ca}_{2.94} \mathrm{Na}_{0.06} \mathrm{Mn}_{2} \mathrm{O}_{7}$, AIP Advances, 8, 015009, 2018.

[21] Wang, R.L., Lee, M.K., Xu, L.S., Sun, Z.G., Marchenkov, V. V., Tien, C., Huang, J.C.A., Yang, C.P., Effect of thermal cycle on the interfacial antiferromagnetic spin configuration and exchange bias in Ni-Mn-Sb alloy, AIP Advances, 2, 032181, 2012.

[22] Fertman, E.L., Fedorchenko, A. V., Desnenko, V.A., Shvartsman, V. V., Lupascu, D.C., Salamon, S., Wende, H., Vaisburd, A.I., Stanulis, A., Ramanauskas, R., Olekhnovich, N.M., Pushkarev, A. V., Radyush, Y. V., Khalyavin, D.D., Salak, A.N., Exchange bias effect in bulk multiferroic BiFe $0.5 \mathrm{Sc}_{0.5} \mathrm{O}_{3}$, AIP Advances, 10, 045102, 2020.

[23] Abulyazied, D.E., Abomostafa, H.M., El komy, G.M., Magnetic structured nickel core-shell@ silica/PMMA nanocomposites from synthesis to applications, Journal of Inorganic and Organometallic Polymers and Materials, 30, 2335-2346, 2020. 